\title{
Development of Soy Milk in Litchi Pulp Based Shrikhand for Development of a Novel Fermented Milk Product
}

\author{
Smriti Sharma ${ }^{1}$, D. C. Rai ${ }^{2}$, Uday Pratap Singh ${ }^{2 *}$ and Dhruvendra Vikram Singh ${ }^{2}$ \\ ${ }^{1}$ Department of kaya Chikitsa Institute of Medical Sciences, Banaras Hindu University \\ Varanasi, 221005, UP, India \\ ${ }^{2}$ Department of Animal Husbandry and Dairying, Institute of Agricultural Sciences, Banaras \\ Hindu University, Varanasi-221005, UP, India \\ *Corresponding author
}

\begin{abstract}
A B S T R A C T

\begin{tabular}{|c|}
\hline Keywords \\
\hline $\begin{array}{l}\text { Shrikhand, litchi pulp, } \\
\text { standardized milk, soy } \\
\text { milk, quality }\end{array}$ \\
\hline Article Info \\
\hline $\begin{array}{l}\text { Accepted: } \\
25 \text { May } 2018 \\
\text { Available Online: } \\
\text { 10 June } 2018\end{array}$ \\
\hline
\end{tabular}

The present investigation was undertaken to explore the possibility of the use of soy milk in litchi pulp based shrikhand to produce a novel fermented milk product. The product was prepared as per the standard method using constant level of litchi pulp (15\%) and sugar (40\%). Different levels of soy milk $(10,20,30$ and $40 \%)$ were tried as substitute of standardized milk. It was found that incorporation of soy milk at $20 \%$ level slightly improved the colour and appearance scores of the developed product. Other sensory parameter (Flavour, Body and texture, Sweetness and Overall Acceptability) scores were decreased as the level of soy milk incorporation increased, but the scores were comparable with control samples at $20 \%$ soy milk incorporation. The moisture and protein content was increased and fat, titrable acidity and total solids were decreased in $20 \%$ soy milk incorporated developed shrikhand. It is concluded that litchi pulp (15\%) based shrikhand can be prepared by replacing $20 \%$ soy milk with standardized milk without compromising its quality.
\end{abstract}

\section{Introduction}

Fermented milk products constitute a vital component of the human diet in many regions of the world (Swapna and Chavannavar, 2013). Indian fermented milk products utilize 7 per cent of total milk produced and mainly include three sweetened products i.e. dahi, shrikhand and lassi. These products have enjoyed reputation for their nutritional and therapeutic value from time immemorial (Aneja et al., 2002) and play an important role in synthesis of vitamin B complex in human body. These products also prevent the stomachic diseases, because several lactic organisms produce natural antibiotics (Zhao et al., 2006). Shrikhand is popular dessert and forms part of a delicious supplement on religious functions, particularly in the state of Maharashtra, Gujarat, Karnataka and some parts of South India (Aneja et al., 2002).

With the restricted availability and high cost of animal milk, the scientists have been making attempts to switch over to the utilization of plant proteins. Soya bean is 
nutritious and used to prepare soy milk based fermented food products. Fermentation of soy milk improves the flavour, enhances the nutritional quality of food, increases the digestibility, eliminates the anti-nutritional factors, prolongs shelf life, adds therapeutic value and is relatively economic as compared to dairy milk products (Hasseltine and Wanghua, 1980).

Litchi (Litchi chinensis Sonn.) is a tropical and subtropical fruit native to China, and now widely Cultivated throughout the World. It is well received by consumers because of its delicious taste and possible health benefits, and its processing production has steadily increased in late decades. Litchi fruit pericarp (LFP) accounts for approximately $15 \%$ by weight of the whole fresh fruit and contains significant amounts of phenolics which are usually discarded as a waste in the process (Gavane et al., 2010; Deshpande et al., 2008). The phenolics of LFP have been confirmed to have antioxidant, anticancer (Gandhi and Jain, 1977), immunomodulatory (9) activities. LFP has been considered a new source of pharmaceuticals and food industry.

Soy milk based fruit juice beverage would offer several distinct nutritional advantages over the plain fruit beverage to the consumer.

It is also a common practice of using fruits in preparation of various dairy products like ice cream, yoghurt and shrikhand (Zhao et al., 2006). Fruit pulp provides sweetness and masks the beany flavor of soy milk to some extent (Lee et al., 1990). Various workers have tried pulp of various fruits in the preparation of shrikhand (Gavane et al., 2010).

Hence, the present investigation was undertaken to explore the possibility of the use of soy milk in litchi pulp based shrikhand to produce a novel fermented milk product.

\section{Materials and Methods}

Soy bean, litchi fruits and powdered Sugar were purchased from local market and fruit pulp was used for enhancing the flavour and acceptability of product.

Standardized milk having $4.5 \%$ fat and $8.5 \%$ SNF was purchased from local market of Varanasi Uttar Pradesh and the mixed starter culture NCDC-263 (Streptococcus thermophiles and Lactobacillus bulgaricus) was procured from National Collection of Dairy Cultures, NDRI, Karnal.

The litchi pulps were prepared with standard methods in hygienic conditions and pasteurization was done at $76{ }^{\circ} \mathrm{C}$ for $1 \mathrm{~min}$. The pulp were packaged in polythene bags and sealed aseptically.

Soy milk was prepared in the Animal Husbandry and Dairyinginstitute of agricultural sciences Banaras Hindu University Varanasi as per standard procedures (Deshpande et al., 2008) and packed in glass bottles. Both the ingredients were shifted to cold storage $\left(4 \pm 1{ }^{0} \mathrm{C}\right)$ room for further use (Gandhi and Jain, 1977).

Treatments were prepared by replacing standardized milk with soy milk at different levels (10, 20, 30 and 40\%). Litchi pulp (15\%) and sugar $(40 \%)$ was added to both control and treated samples as per the standardized method (Zhao et al., 2006; Thakur et al., 2014) and further processed for preparation of shrikhand as per the method followed by Sonawane (Zhao et al., 2006).

Method of Trout (Trout et al., 1992) was followed for determining the $\mathrm{pH}$ of the samples and the acidity (titration) and proximate composition of sample were determined by following the method described by AOAC (AOAC, 2002). 
The nine point hedonic scale was employed for sensory evaluation following the methodology described by Harry and Hildegarde (Harry and Hildegarde, 1998).

The experiment was replicated thrice along with duplicate samples and data obtained were subjected to one way ANOVA followed by Duncans Multiple Range Test by using SPSS software (Snedecor and Cochran, 1994).

\section{Results and Discussion}

\section{Sensory Evaluation}

The colour and appearance score was slightly improved with addition of soy milk at T1 and $\mathrm{T} 2$ treatment levels as compared to control (C) for development of litchi based shrikhand (Table 1), however, it was significantly $(p \leq 0.05)$ decreased with further incorporation of soy milk (T3 and T4) as compared to control as well as T1 and T2 samples. The colour and appearance scores of T2 were statistically comparable with $\mathrm{C}$, and hence selected. These results of colour and appearance for soya milk incorporation are in accordance with the findings of Despande (Deshpande et al., 2008; Deshpande et al., 2005; Deshpande et al., 2008). Who reported lower average colour and appearance in shrikhand prepared from buffalo milk blended at higher levels of soy milk as compared to control.

It was evident from the results that the flavor score was decreased as the level of soy milk increased. It was due to beany flavor of soy milk as reported by (Deshpande et al., 2006). The treatment T2 was selected by judges because it contain higher proportion of soy milk than T1 with acceptable scores and statistically comparable with control samples. The lower flavor score in soy milk incorporated shrikhand are in agreement with the results of (Deshpande et al., 2008) and
(Borate et al., 2011), who reported lower average flavor score in shrikhand prepared from buffalo milk blended at higher levels of soy milk due to its dominating beany flavor as compared to control.

The body and texture score was slightly decreased with addition of soy milk at T1 and $\mathrm{T} 2$ treatment levels as compared to control (C) for development of litchi based shrikhand, however, it was significantly $(p \leq 0.05)$ decreased with further incorporation of soy milk as compared to control as well as T1 and $\mathrm{T} 2$ samples. The body and texture scores of $\mathrm{T} 2$ were statistically comparable with $\mathrm{C}$, and hence selected. (Deshpande et al., 2006) also reported the similar results for body and texture scores with incorporation of soy milk in standardized buffalo milks shrikhand. The lower body and texture scores in soy milk incorporated shrikhand are also in agreement with the results of (Deshpande et al., 2008) and (Borate et al., 2011). However, the sweetness scores were decreased as the level of soy milk incorporation increased, but the significant decline was recorded at $\mathrm{T} 3$ and $\mathrm{T} 4$ levels of treatments as compared to $\mathrm{C}$ including $\mathrm{T} 1$ and $\mathrm{T} 2$ treatments. The sweetness score of treatment T2 was comparable with control and hence selected. These results of soy milk incorporated shrikhand might be due to higher acidity and lower average sweetness scores in shrikhand prepared from buffalo milk blended with soy milk as compared to control samples (Deshpande et al., 2008; Borate et al., 2011). The overall acceptability score was slightly decreased with addition of soy milk at T1 and $\mathrm{T} 2$ treatment levels as compared to control for development of litchi based shrikhand, however, it was significantly $(p \leq 0.05)$ decreased with further incorporation of soy milk at T3 and T4 as compared to $\mathrm{C}$ as well as $\mathrm{T} 1$ and $\mathrm{T} 2$ samples. The overall acceptability scores of $\mathrm{T} 2$ treatment were statistically comparable with $\mathrm{C}$. 
Table.1 Effect of soy milk incorporation on sensory score of litchi pulp based shrikhand

\begin{tabular}{|l|l|l|l|l|l|}
\hline Sensory attributes & $\mathrm{C}$ & $\mathrm{T}_{1}$ & $\mathrm{~T}_{2}$ & $\mathrm{~T}_{3}$ & $\mathrm{~T}_{4}$ \\
\hline Colour and appearance & $7.86^{\mathrm{a}} \pm 0.16$ & $8.00^{\mathrm{a}} \pm 0.00$ & $8.00^{\mathrm{a}} \pm 0.00$ & $7.56^{\mathrm{b}} \pm 0.21$ & $7.00^{\mathrm{b}} \pm 0.36$ \\
\hline Flavour & $8.18^{\mathrm{a}} \pm 0.25$ & $7.93^{\mathrm{a}} \pm 0.16$ & $7.65^{\mathrm{a}} \pm 0.20$ & $7.00^{\mathrm{b}} \pm 0.12$ & $6.42^{\mathrm{c}} \pm 0.20$ \\
\hline Body and texture & $8.23^{\mathrm{a}} \pm 0.32$ & $7.82^{\mathrm{a}} \pm 0.83$ & $8.08^{\mathrm{a}} \pm 0.20$ & $7.18^{\mathrm{b}} \pm 0.08$ & $6.42^{\mathrm{c}} \pm 0.20$ \\
\hline Sweetness & $8.40^{\mathrm{a}} \pm 0.25$ & $7.93^{\mathrm{a}} \pm 0.16$ & $7.53^{\mathrm{a}} \pm 0.16$ & $7.20^{\mathrm{b}} \pm 0.10$ & $6.33^{\mathrm{c}} \pm 0.21$ \\
\hline Overall acceptability & $7.83 \mathrm{a} \pm 0.16$ & $7.73 \mathrm{a} \pm 0.10$ & $7.75 \mathrm{a} \pm 0.17$ & $6.67 \mathrm{~b} \pm 0.16$ & $6.00 \mathrm{c} \pm 0.00$ \\
\hline
\end{tabular}

Table.2 Physico Chemical properties of soy milk blended litchi based shrinkhand

\begin{tabular}{|c|c|c|c|}
\hline \multirow[b]{2}{*}{ Parameters } & \multicolumn{3}{|l|}{ Treatment } \\
\hline & $\begin{array}{l}\text { Strawberry based } \\
\text { (Control) }\end{array}$ & Shrikhand & $\begin{array}{l}\text { Litchi based Shrikhand with } 20 \% \\
\text { Soya milk }\end{array}$ \\
\hline Moisture (\%) & $51.73^{\mathrm{b}} \pm 0.24$ & & $54.87^{\mathrm{a}} \pm 0.11$ \\
\hline Total Solids (\%) & $48.27^{\mathrm{a}} \pm 0.21$ & & $45.13^{\mathrm{b}} \pm 0.32$ \\
\hline Protein $(\%)$ & $5.60^{\mathrm{b}} \pm 0.03$ & & $6.47^{\mathrm{a}} \pm 0.04$ \\
\hline Fat $(\%)$ & $8.92^{\mathrm{a}} \pm 0.01$ & & $7.12^{b} \pm 0.08$ \\
\hline $\operatorname{Ash}(\%)$ & $0.57 \pm 0.03$ & & $0.55 \pm 0.02$ \\
\hline Sucrose $(\%)$ & $24.92 \pm 0.72$ & & $24.29 \pm 0.83$ \\
\hline pH & $3.71 \pm 0.02$ & & $3.74 \pm 0.05$ \\
\hline Titrableacidity (\%) & $1.62^{\mathrm{a}} \pm 0.01$ & & $1.45^{\mathrm{b}} \pm 0.04$ \\
\hline
\end{tabular}

\section{Treatments}

\begin{tabular}{|l|l|l|}
\hline Control (C) & \multicolumn{2}{|c|}{ Chakka prepared from 100\% standardized milk. } \\
\hline T1 & Chakka prepared from 90\% standardized milk & $10 \%$ soy milk \\
\hline T2 & Chakka prepared from 80\% standardized milk & $20 \%$ soy milk. \\
\hline T3 & Chakka prepared from 70\% standardized milk & $30 \%$ soy milk. \\
\hline T4 & Chakka prepared from 60\% standardized milk & $40 \%$ soy milk. \\
\hline
\end{tabular}

The lower acceptability scores at higher level of soy milk incorporated shrikhand are also in agreement with the results of (Deshpande et al., 2008) and (Borate et al., 2011). On the basis of sensory evaluation, the litchi $(15 \%)$ based shrikhand incorporated with $20 \%$ soya milk was selected for further studies.

\section{Physico-chemical properties}

Moisture content strawberry (15\%) based shrikhand was significantly $\quad(P \leq 0.05)$ increased with addition of $20 \%$ soy milk (Table 2). Total solids of control was significantly $(P \leq 0.05)$ higher than soya milk added product. This might be due to the fact that soy proteins have high affinity for water binding and thus having high water holding capacity. Similar results were also reported by (Deshpande et al., 2008; Deshpande et al., 2005) and (Borate et al., 2011)

There was a significant $(P \leq 0.05)$ increase in protein content of soya milk added shrikhand 
as compared to control. Present findings for protein content of soy milk blended shrikhand are in line with that reported by (Borate et al., 2011). Fat content of soya milk added shrikhand was significantly $(P \leq 0.05)$ lower than control. It might be due to more water retained in soy milk added shrikhand which affected the proportionate nutritional parameters (Deshpande et al., 2008; Deshpande et al., 2005; Borate et al., 2011).

Ash, sucrose content and $\mathrm{pH}$ level did not show any significant $(P \leq 0.05)$ differences between control and soya milk treated shrikhand and the $\mathrm{pH}$ value of developed shrikhand and control sample were within the range prescribed by Datta and Ghatak (Datta and Ghatak, 2001).

The per cent titrable acidity of control shrikhand was significantly $(P \leq 0.05)$ higher than that of titrable acidity of soya milk added developed product. Lower acidity in the fresh shrikhand prepared from buffalo milk blended with soy milk has been reported than shrikhand prepared only from buffalo milk (Borate et al., 2011). However, the titrable acidity in both control and soya treated products was found well within the permissible limits of 1.4 per cent as per the BIS specification for shrikhand.

It is concluded that litchi pulp based shrikhand can be prepared with incorporation of $20 \%$ soy milk without compromising the sensory, nutritional and physico-chemical quality of the developed shrikhand.

\section{References}

Aneja RP, Mathur BN, Chandan RC, Banerjee AK. Technology of Indian milk products. Dairy India Publication, Delhi, India, 2002.

AOAC. Official Methods of Analysis, 17th edition, Association of Official
Analytical Chemists, Washington, DC, 2002.

Borate AJ, Gubbawar SG, Shelke RR, Chavan SD. Studies on keeping quality of Shrikhand prepared from buffalo milk blended with soy milk. Food Sci. Res. J. 2011; 2(2): 205-210.

Datta S, and Ghatak PK. Shrikhand-A review. J Dairy Food and Home Sci. 2001; 20:141-148.

Deshpande S, Bargale PC, Jha K. Quality and acceptability of soy milk based amrakhand. J. Dairying, Foods and Home Sci. 2005; 24(1): 16-19.

Deshpande S, Bargale PC, Jha K. Soy amrakhand - Nutritive food product. Udyamita. 2006; 10: 46.

Deshpande S, Bargale PC, Jha K. Suitability of soy milk for development of shrikhand. J Food Sci. Technol. 2008; 45(3): 284-286.

Deshpande S, Bargale PC, Jha K. Suitability of soy milk for development of shrikhand. J Food Sci. Technol. 2008; 45(3): 284-286.

Gandhi NM, and Jain SC. A study on the development of a new high protein formulated food using buffalo milk. J. Food Sci. Technol. 1977; 14:156.

Gavane PF, Zinjarde RM, Rokde SN. Studies on preparation of shrikhand blended with custard apple pulp-A new fermented milk product. Indian J Dairy Sci. 2010; 63(1): 11-15.

Harry TL, and Hildegarde H. Sensory evaluation of food. Chapman and Hall, New York, 1998.

Hasseltine CW, and Wanghua HL. The importance of traditional fermented foods. Bioscience. 1980; 30: 402-404.

Lee SY, Morr CV, Seo A. Comparison of milk based and soymilk based yogurt. J Food Sci. 1990; 55: 532-536.

Li, J.R.; Jiang, Y.M. Litchi flavonoids: Isolation, identification and biological activity. Molecules 2007, 12, 745-758. 
Snedecor GW, and Cochran WG. Statistical Methods. VIII edn. Oxford and IBH Publishing Co., New Delhi, 1994.

Swapna G, and Chavannavar SV. Shrikhand Value added traditional dairy product. Inter. J Food Nutri. Sci. 2013; 2(4):4551.

Thakur SN, Rajni Kant, Chandra R. Preparation of Shrikhand by using mango pulp. Bioved. 2014; 25(1): 7982.

Trout ES, Hunt MC, Jhonson DE, Clans JR, Castner CL, Kropt DH. Characteristics of low fat ground beef containing texture modifying ingredients. J Food Sci. 1992; 57: 19.

Wang, X.J.; Yuan, S.L.; Wang, J.; Lin, P.; Liu, G.J.; Lu, Y.R.; Zhang, J.; Wang,
W.D.; Wei, Y.Q. Anticancer activity of litchi fruit pericarp extract against human breast cancer in vitro and in vivo. Toxicol. Appl. Pharmacol. 2006, $215,168-178$.

Zhao, M.M.; Yang, B.; Wang, J.S.; Li, B.Z.; Jiang, Y.M. Identification of the major flavonoids from pericarp tissues of lychee fruit in relation to their antioxidant activities. Food Chem. 2006, 98, 539-544.

Zhao, M.M.; Yang, B.; Wang, J.S.; Liu, Y.; Yu, L.M.; Jiang, Y.M. Immunomodulatory andanticancer activities of flavonoids extracted from litchi (Litchi chinensis Sonn.) pericarp. Int. Immunopharmacol. 2007, 7, 162166.

\section{How to cite this article:}

Smriti Sharma, D. C. Rai, Uday Pratap Singh and Dhruvendra Vikram Singh. 2018. Development of Soy Milk in Litchi Pulp Based Shrikhand for Development of a Novel Fermented Milk Product. Int.J.Curr.Microbiol.App.Sci. 7(06): 3794-3799. doi: https://doi.org/10.20546/ijcmas.2018.706.445 